\title{
How Important are OCB as Mediation in Relationship Between Job Satisfaction, Motivation, Organizational Comittments, and Organizational Performance
}

\author{
Meilia Risna ${ }^{1}$, Che Musa Che Omar ${ }^{2}$ \\ \{meiliarisna.jktm@gmail.com ${ }^{1}$, chemusa@unikl.edu.my²\} \\ ${ }^{1}$ Universitas Trilogi - Jakarta, Indonesia \\ ${ }^{2}$ UniKL Business School - Malaysia
}

\begin{abstract}
Schermerhorn, Hunt and Osborn said that company performance determined by the human resources/human capital. Human capital runs the company, creates innovation and improvement in order to achieve the company's goals such as operational excellence, incremental profitability and cost effectiveness. Konopaske, Ivancevic and Matteson, Schermerhorn, Hunt and Osborn, Robbin and Coulter said that company performance can be influenced by employee job satisfaction, organizational commitment and Organizational citizenship behavior (OCB). This research use primary data and to gather the data we use census method to ask 173 state owned firm employees, using questionnaire with Likert scale. Data processed using Structural Equations Method (SEM) with Smart PLS data analysis. This study indicate that job satisfaction has no effect on organizational performance either directly or mediated by $\mathrm{OCB}$, but motivation influences organizational performance by being fully mediated by OCB. In other hands, organizational commitment affects organizational performance both directly and through OCB, so its mean OCB partially mediated the relationship between organizational commitment and organizational performance.
\end{abstract}

Keywords: Job Satisfaction, Motivation, Organizational Commitment, OCB and Organizational Performance

\section{Introduction}

Consumer changes desires and technological developments change consumer behavior. Consumers want their package and document delivery services to be faster, precise and cheaper. On the other hand the emergence of ecommerce and transportation start-up companies with low barrier to entry. This has become a big trigger for companies to immediately improve in the face of VUCA's era. So that companies can appear to compete and grow. Best to provide better service is one's strategy to complite in the very tight competition. Competitors had been around 15 years earlier and began to focus on domestic and international e-commerce distribution.

Internal factors found strength in the otlet networks spread across 24 sub-districts plus 2 mobile post services and two open table otlets at the immigration office and the Karawang District Court Office. The organization also has 175 employees who work 7 days a week. When the National Online Shopping Day in December 2018, the company only gets market share $7.5 \%$ from the potential e-commerce market in Karawang Regency. There was a decline in sales in the fourth quarter of 2018 due to a large account customer that bankrupt and did 
not produce anymore. This has an impact on not achieving sales targets. Direct operating costs continued to grow to $14.1 \%$ influenced by increases in electricity, fuel and special minimum wages (UMR) in the Karawang district.

Human resources play an important role in achieving company goals. Humans are active, living resources, and are always involved in company activities, so it is necessary to manage these human resources properly and accurately. According to Dessler human resource management (HRM) is the process of obtaining, training, assessing and giving rewards or compensation to employees, paying attention to their work relations, health and safety, and issues of justice[1]. Meanwhile according to Robbins and Coulter that human resource management (HRM) refers to the process of coordinating and integrating work activities so that they are completed efficiently and effectively[2]. "A team is a place when two or more people interact dynamically and interactively and share a common and value goal, objective or mission". Aguinis explains that a team is a container in which one or several people will interact dynamically and depend on each other and share the goals, strategies and mission of the organization[3]. The same thing was expressed by Kreitner and Kinicki that some of the efforts needed in improving performance include: feedback, giving awards and providing positive reinforcement to the team[4].

An effective organizations need employees who will do more than their formal duties and are willing to deliver performance that beyond the expectations. Organization will focus on human resources in order to carry out the company's functions optimally, especially in the face of environmental changes that occur, so that the company can still survive and grow at strong competition at this time. Companies can stay afloat and grow because the innovation side of a product lies with humans themselves. So that human resources as key assets are very important for the development and achievement of organizational goals. Companies need the participation of employees to do the best for the organization. The quality of human resources can be seen, not only from how many employees are able to contribute and able to complete all their tasks well, but it can be seen how many employees have their own initiative in completing other work outside of the job description. An important element that needs attention in organizations is extra-roles activities.

Organizational Citizenship Behavior (OCB) is individual behavior that is carried out voluntarily without expecting reward. This behavior can affect the performance of employees and organizations. Firstly, OCB was introduced by Smith, Organ and Near in 1983. This action is actually very synonymous with Indonesian culture which promotes mutual cooperation or helping-behavior (called, gotong royong).

The current perspective of employees is changing. A person's performance is often determined by material elements only, whereas there are other values such as good relations, help, brotherhood and trust. Therefore, it is very important to have citizenship behavior at work[5]. Organizations that have high OCB will produce high organizational performance, because OCB increases collaboration in one team and dependence on members from each other.

This study, examined the effect of OCB on the relationship between employee job satisfaction, motivation and organizational commitment with Organizational Performance. Located in Karawang post offices. This post office ranks worst of the worst growth of revenue and production. This study intends to determine the effect of OCB as a mediating factor for the relationship between employee job satisfaction, motivation, and organizational commitment with organizational performance. This study aims to explain the effect of variable job satisfaction (X1), motivation (X2), organizational commitment (X3), and OCB (Z) on Organizational Performance (Y). 


\section{Literature Review}

Job satisfaction constructs are measured using the indicators "lear rules", "firmness of sanctions" and "harmonious relationship between leader and subordinates" Supit[6] and Zang[7]. Motivation constructs are measured using the indicators "exemplery Bos", "Easy to convey proposed improvements" and "Get help from superiors if difficulties" Jarwanto[8], Mushtaq[9] and Nurnaningsih S. and Wahyono[10]. Organizational commitment constructs are measured using the indicators "talk about positive things", "feel part of the company" and "proud" Hasanreza[11], Prasetyo[12], Sawitri[13], Sani[14]. Organizational citizenship behavior are measured using the indicators "attendance", "obedient" and "advised" Podsakoff, Mc Kenzie, paine and Bachrach[15] and Sani[14]. Organizational Performance constructs are measured using " customer satisfaction", "cost effectiveness" , "handling complain within 48 hours" and "integrity" Sani[14] and Sawitri[13].

\section{Research Methode}

\subsection{Description of Responden}

This study distributed 173 questionnaires to all employee permanent and contract with $63 \%$ responden are male, $79 \%$ are permanent employee's, 20,8\% employee more than 50 years old, $37 \%$ have more than 2 until 10 years period of employment, $71 \%$ are high school degree, $55 \%$ employee worked as the first job, $78 \%$ are staff, $71 \%$ married, $54 \%$ have no work for the couple's and $67 \%$ employee have children.

Tabel 1. Description of Responden

\begin{tabular}{|c|c|c|c|c|c|}
\hline Description & Frequency & Precentage & Description & Frequency & Precentage \\
\hline Gender & & & Employment status & & \\
\hline Male & 109 & $63 \%$ & Permanent & 137 & $79 \%$ \\
\hline Female & 64 & $37 \%$ & Contract & 36 & $21 \%$ \\
\hline Total & 173 & $100 \%$ & Total & 173 & $100 \%$ \\
\hline Age & & & \multicolumn{3}{|l|}{ Period of employment } \\
\hline$<25$ years & 22 & $12,7 \%$ & $<2$ years & 33 & $19 \%$ \\
\hline $25-35$ years & 54 & $31,2 \%$ & $>2-10$ years & 64 & $37 \%$ \\
\hline$>35-45$ years & 33 & $19,1 \%$ & $>10-20$ years & 19 & $11 \%$ \\
\hline$>45-50$ years & 28 & $16,2 \%$ & $>20$ years & 57 & $33 \%$ \\
\hline$>50-55$ years & 36 & $20,8 \%$ & Others & 0 & $0 \%$ \\
\hline Total & 173 & $100,0 \%$ & Total & 173 & $100 \%$ \\
\hline Level of education & & & \multicolumn{2}{|l|}{ Previous work } & \\
\hline High school & 123 & $71 \%$ & No work & 95 & $55 \%$ \\
\hline Diploma & 18 & $10 \%$ & have worked before & 64 & $37 \%$ \\
\hline Bachelor & 32 & $18 \%$ & Entrepreneur & 14 & $8 \%$ \\
\hline Total & 173 & $100 \%$ & Total & 173 & $100 \%$ \\
\hline
\end{tabular}




\begin{tabular}{|c|c|c|c|c|c|}
\hline Level of Position & & & Couples Work & & \\
\hline Staff & 135 & $78 \%$ & Entrepreneur & 23 & $13 \%$ \\
\hline Head of Branch Office & 24 & $14 \%$ & Employee & 57 & $33 \%$ \\
\hline Management & 14 & $8 \%$ & Does not work & 93 & $54 \%$ \\
\hline Total & 173 & $100 \%$ & Total & 173 & $100 \%$ \\
\hline Marital status & & & Number of children & & \\
\hline Married & 123 & $71 \%$ & Have & 116 & $67 \%$ \\
\hline Single & 45 & $26 \%$ & No & 57 & $33 \%$ \\
\hline Divorce & 5 & $3 \%$ & Total & 173 & $100 \%$ \\
\hline Total & 173 & $100 \%$ & & & \\
\hline
\end{tabular}

Source: Primary data 2019

\subsection{Description of Variable}

This study has four constructs are job satisfaction, organizational commitment, OCB and organizational performance have 34 questionnaires consisting of job satisfaction 8 questionnaires, motivation 5 questionnaires, organizational commitment 7 questionnaires, OCB 7 questionnaires and organizational performance 7 questionnaires. 173 respondents who filled out the questionnaire.

This study using the Partial Least Square (PLS) method for Hypothesis testing . PLS is an alternative method of analysis with variance based Structural Equation Modeling (SEM). The advantage of this method is that it does not require assumptions and can be estimated with a relatively small number of samples. The tool used is a SmartPLS Version 3.2.7 program specifically designed to estimate structural equations on the basis of variance. The SmartPLS Version 3.2.7 program can be obtained for free at www.smartpls.de.

\subsection{Hypothesis}

This study has three hypothesis, such as :

Hipotesis 1 (H1) : OCB has positive and significant influence on relationship between Job Satisfaction and Organizational Performance

Hipotesis $2(\mathrm{H} 2)$ : OCB has positive and significant influence on relationship between motivation and Organizational Performance

Hipotesis 3 (H3) : OCB has positive and significant influence on relationship between Organizational Commitment and Organizational Performance.

Finally after drop 18 indicator, based on the existing hypothesis, the three hypotheses are presented in a path diagram as shown in Figure 1 below. 


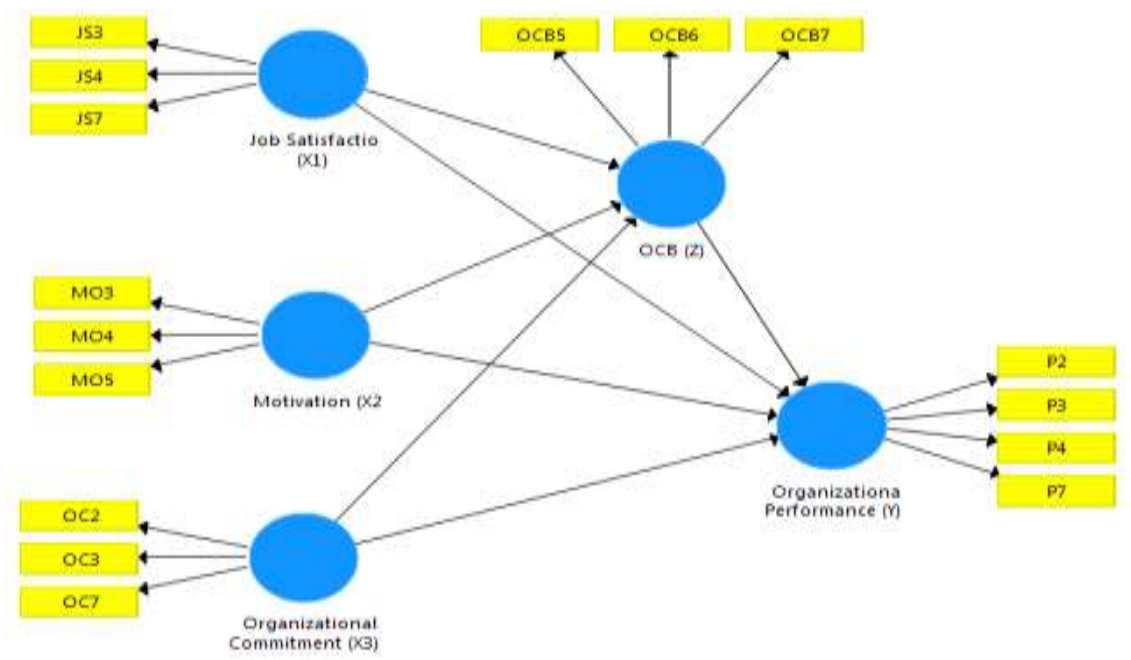

Fig 1. Structural Model

The construct of Job Satisfaction (JS) is measured by 3 indicators, namely JS3, JS4 and JS7. The construct of Motivation (MO) is measured by 3 indicators, namely MO3, MO4 and MO5. Likewise, the construct of Organizational Commitment (OC) is measured by 3 indicators namely OC2, OC3 and OC7, the construct of Organizational Citizenship Behavior (OCB) is measured by 3 indicators namely OCB5, OCB6 and OCB7 and contract Organizational Performance (P) is measured by 4 indicators namely P2, P3, P4 and P7. The direction of the arrow between indicators with latent constructs is towards indicators that show that research uses reflective indicators that are relatively appropriate for measuring perceptions. The relationship to be examined (hypothesis) is symbolized by an arrow between constructs.

\section{Measurement of Outer Model}

\subsection{Validity Test}

An indicator is declared valid if it has a loading factor above 0.5 Ghozali towards the intended construct. The SmartPLS output for loading factors gives the following results: Validity testing for reflective indicators uses a correlation between item scores and construct scores. Measurements with reflective indicators indicate a change in an indicator in a construct if other indicators of the same construct change (or are removed from the model). Reflective indicators are suitable for measuring perceptions so that this study uses reflective indicators. The table above shows that the loading factor gives a value above the recommended value of 0.6. The smallest value is 0.661 for the JS4 indicator. Means the indicators used in this study are valid or have met convergent validity.

The latent contracts predict indicators on their blocks better than indicators on other blocks. Another method for looking at discriminant validity is to look at the square root of average variance extracted (AVE) value. The recommended value is above 0.5 . The following are the AVE values in this study: 
Tabel 2. Composite Reliability and Average Variance Extracted (AVE)

\begin{tabular}{|l|r|r|}
\hline \multicolumn{1}{|c|}{ Construct } & $\begin{array}{l}\text { Composite } \\
\text { Reliability }\end{array}$ & \multicolumn{1}{|c|}{$\begin{array}{l}\text { Average Variance } \\
\text { Extracted (AVE) }\end{array}$} \\
\hline Job Satisfaction (X1) & 0,772 \\
\hline Motivation (X2) & 0,803 & 0,533 \\
\hline OCB $(\mathrm{Z})$ & 0,828 & 0,576 \\
\hline Organizational Commitment $(\mathrm{X} 3)$ & 0,823 & 0,618 \\
\hline Organizational Performance $(\mathrm{Y})$ & 0,812 & 0,609 \\
\hline
\end{tabular}

Source: Smart PLS 32 7_2019

In table 4 above illustrating the intended construct is greater than the loading value of another construct. Diagonal is the square root value of AVE and the value below is the correlation between constructs. So it is seen that the AVE square root value is higher than the correlation value between constructs, where the AVE square root value on OCB (Z) against OC (X2) is higher than the AVE squared value at OC (X2) against OC (X2) which is 0.550 and $\mathrm{P}(\mathrm{Y})$ to $\mathrm{OC}(\mathrm{X} 2)$ is 0.705 . Also the AVE square of OC (X2) against OCB (Z) has a value of 0.876 higher than the correlation value between the constructs below that is $\mathrm{P}(\mathrm{Y})$ against OCB (Z) of 0.463 . Then it can be concluded that the model is valid because it fulfills discriminant validity.

Based on testing of the outer model measurement model with the average analysis of AVE, Loading Factor and Composite Reliability can be ascertained that 16 indicators are suitable to be used as a measurement based on validity and reliability of the construct, because the original sample has a value of more than 0.6 , with T-statistics greater than 1.96 and Composite Reliability has diagonally higher values than the constructs before and below it.

These indicators or constructs meet vaild and reliable requirements because value of the origin sample more than 0,6 with T-statistic of JS4 lower than 1,96 as indicator "firmness of the sanctions" only 0,661 .

Tabel 3. Measurement of outer model

\begin{tabular}{|l|r|r|r|r|r|l|}
\hline \multicolumn{1}{|c|}{ Indicator and Variabel } & \multicolumn{1}{|c|}{$\begin{array}{c}\text { Origin } \\
\text { Sampel } \\
\text { (O) }\end{array}$} & $\begin{array}{c}\text { Mean } \\
\text { (M) }\end{array}$ & STDEV & $\begin{array}{c}\text { T } \\
\text { Statistics }\end{array}$ & \multicolumn{1}{c|}{$\begin{array}{c}\text { P } \\
\text { Values }\end{array}$} & Description of Indicators \\
\hline JS3 <- Job Satisfaction (X1) & 0,682 & 0,680 & 0,078 & 8,757 & 0,000 & Clear rules \\
\hline JS4 <- Job Satisfaction (X1) & 0,661 & 0,649 & 0,104 & 6,327 & 0,000 & $\begin{array}{l}\text { Firmness of application } \\
\text { of sanctions }\end{array}$ \\
\hline JS7 <- Job Satisfaction (X1) & 0,835 & 0,822 & 0,053 & 15,651 & 0,000 & $\begin{array}{l}\text { Harmonious between } \\
\text { superiors and } \\
\text { subordinates }\end{array}$ \\
\hline MO3 <- Motivation (X2) & 0,752 & 0,732 & 0,110 & 6,834 & 0,000 & Exemplary boss \\
\hline MO4 <- Motivation (X2) & 0,741 & 0,729 & 0,113 & 6,551 & 0,000 & $\begin{array}{l}\text { Easy to convey proposed } \\
\text { improvements }\end{array}$ \\
\hline MO5 <- Motivation (X2) & 0,783 & 0,788 & 0,052 & 14,909 & 0,000 & Get help from superiors \\
\hline $\begin{array}{l}\text { OC2 <- Organizational } \\
\text { Commitment (X3) }\end{array}$ & 0,812 & 0,811 & 0,040 & 20,246 & 0,000 & Talk positive things \\
\hline
\end{tabular}




\begin{tabular}{|l|r|r|r|r|r|l|}
\begin{tabular}{|l|r|r|r|} 
OC3 <- Organizational \\
Commitmentt (X3)
\end{tabular} & 0,837 & 0,831 & 0,039 & 21,623 & 0,000 & Feel part of the company \\
\hline $\begin{array}{l}\text { OC7 <- Organizational } \\
\text { Commitment (X3) }\end{array}$ & 0,684 & 0,684 & 0,057 & 12,083 & 0,000 & Proud \\
\hline OCB5 <- OCB (Z) & 0,673 & 0,662 & 0,100 & 6,751 & 0,000 & Presence \\
\hline OCB6 <- OCB (Z) & 0,843 & 0,843 & 0,032 & 26,371 & 0,000 & Obedient \\
\hline OCB7 <- OCB (Z) & 0,830 & 0,832 & 0,024 & 34,461 & 0,000 & Advised \\
\hline $\begin{array}{l}\text { P2 <- Organizational } \\
\text { Performance (Y) }\end{array}$ & 0,726 & 0,727 & 0,043 & 16,704 & 0,000 & Customer satisfaction \\
\hline $\begin{array}{l}\text { P3 <- Organizational } \\
\text { Performance (Y) }\end{array}$ & 0,721 & 0,712 & 0,073 & 9,893 & 0,000 & Cost effectiveness \\
\hline $\begin{array}{l}\text { P4 <- Organizational } \\
\text { Performance (Y) } \\
\text { P7 <- Organizational } \\
\text { Performance (Y) }\end{array}$ & 0,762 & 0,761 & 0,044 & 17,356 & 0,000 & $\begin{array}{l}48 \text { hours for Customer } \\
\text { handling complaints } \\
\text { solutions } \\
\text { Integrity }\end{array}$ \\
\hline
\end{tabular}

Source: Smart PLS 32 7_2019

The following is a diagram of loading factors for each indicator in the research model:

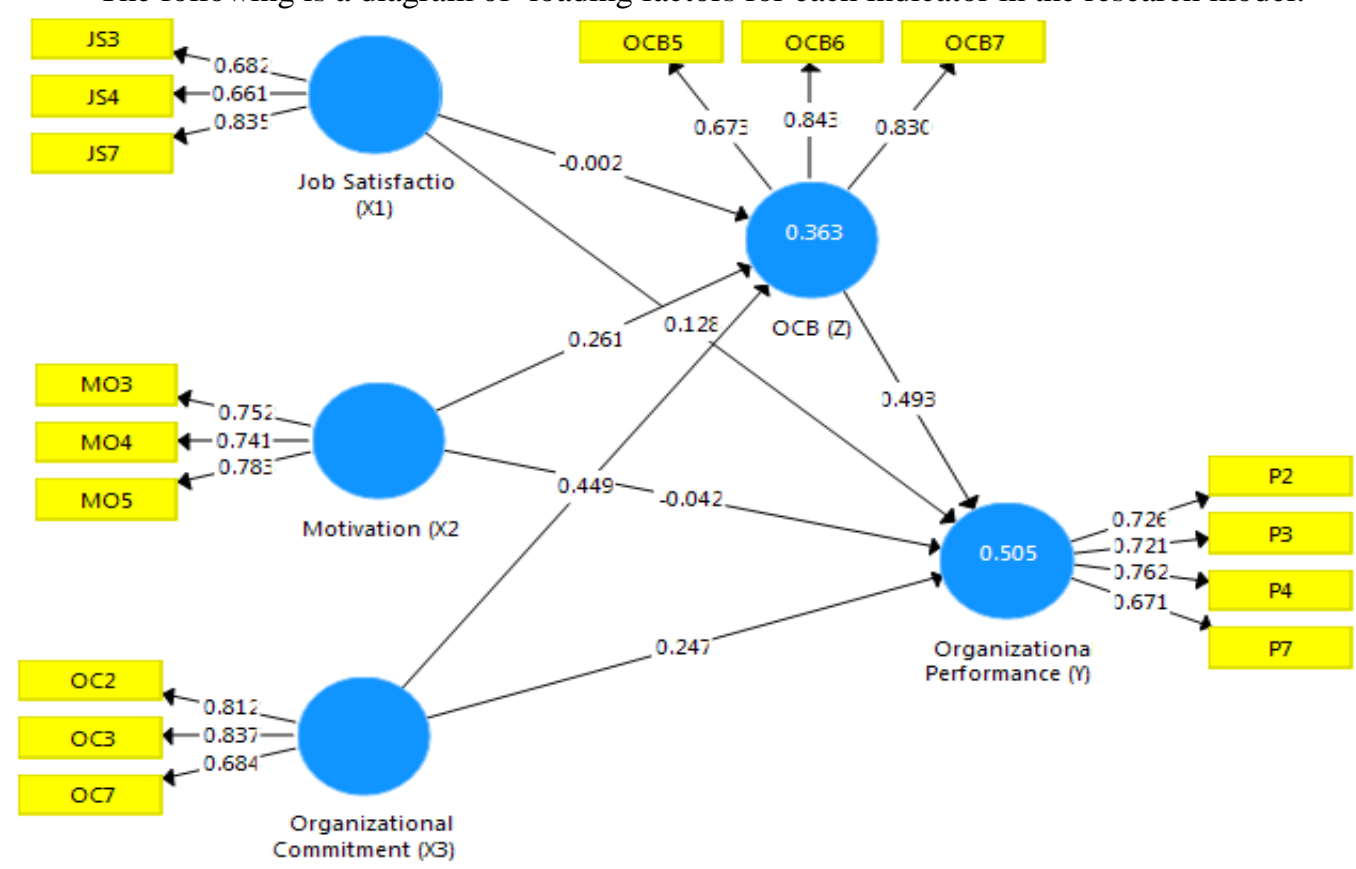

Fig 2. Value of the Diagram of Loading Factor

Based on testing of the outer model measurement model with the average analysis of AVE, Loading Factor and Composite Reliability can be ascertained that 16 indicators are 
suitable to be used as a measurement based on validity and reliability of the construct, because the original sample has a value of more than 0.6 , with T-statistics greater than 1.96 and Composite Reliability has diagonally higher values than the constructs before and below it. Thus all indicators or constructs meet valid and reliable requirements. The table above gives AVE values above 0.5 for all constructs found in the research model. The lowest value of AVE is 0.520 in construct $\mathrm{P}$ (Organizational Performance).

\subsection{Reliability Test}

Reliability testing is done by looking at the composite reliability value of the indicator block that measures the construct. The composite reliability results will show a satisfactory value if above 0.7 . The following is the composite reliability value at the output as table 3 above. The table above shows that the composite reliability value for all constructs is above 0.7 which indicates that all constructs in the model estimated meet the criteria of discriminant validity. The lowest composite reliability value is 0.721 in the Performance construct.

The value of discriminant validity is a value of cross loading factor that is useful to determine whether the construct in this study has adequate discriminant by comparing loading values to the intended construct must be greater than the loading value of the other constructs by testing the construct criteria according to Fornell-Larcker and through Cross Loading with the table below.

Tabel 4. Nilai Loading Konstruk Fornell-Larcker Kriteria

\begin{tabular}{|c|c|c|c|c|c|}
\hline & $\begin{array}{c}\text { Job } \\
\text { Satisfaction } \\
(X 1)\end{array}$ & $\begin{array}{l}\text { Motivation } \\
\quad(X 2)\end{array}$ & $\begin{array}{l}\mathrm{OCB} \\
(\mathrm{Z})\end{array}$ & $\begin{array}{l}\text { Organizational } \\
\text { Commitment } \\
\text { (X3) }\end{array}$ & $\begin{array}{l}\text { Organizational } \\
\text { Performance } \\
\text { (Y) }\end{array}$ \\
\hline Job Satisfaction (X1) & 0,730 & & & & \\
\hline Motivation (X2) & 0,496 & 0,759 & & & \\
\hline $\mathrm{OCB}(\mathrm{Z})$ & 0,368 & 0,442 & 0,786 & & \\
\hline $\begin{array}{l}\text { Organizational } \\
\text { Commitment (X3) }\end{array}$ & 0,534 & 0,405 & 0,553 & 0,780 & \\
\hline $\begin{array}{l}\text { Organizational } \\
\text { Performance (Y) }\end{array}$ & 0,420 & 0,339 & 0,658 & 0,571 & 0,721 \\
\hline
\end{tabular}

Source: Smart PLS 32 7_2019

\subsection{Measurement of Structural Models (Inner Model)}

Inner model analysis / structural model analysis is carried out to ensure that the structural model constructed is accurate. Evaluation of inner model can be seen from several indicators, namely the Determination Coefficient (R2), Predictive Relevance (Q2), and Goodness of Fit Index (GoF).

After the estimated model meets the Outer Model criteria, then the structural model (Inner model) is tested. The following is the R-Square value in the construct with the Goodness of Fit (GoF) method. Goodness of Fit $(\mathrm{GoF})$ is measured using R-square dependent latent variables with the same interpretation as regression. Predictive Q-square relevance for structural models, measures how well the observation value is generated by the model and also its parameter estimates. Q-square value> 0 indicates the model has the opposite predictive relevance if the $\mathrm{Q}$-square value $\leq 0$ indicates the model lacks predictive relevance. 
Tabel 5. Koefisien Determinasi $\left(\mathrm{R}^{2}\right)$

\begin{tabular}{|c|c|c|}
\hline Construct & R Square & Adjusted R Square \\
\hline OCB $(\mathrm{Z})$ & 0,329 & 0,321 \\
\hline Performance Organizational (Y) & 0,525 & 0,517 \\
\hline
\end{tabular}

Source: Smart PLS 32 7_2019

To calculate Predictive Relevance Q2 use the following formula:

$\mathrm{Q}^{2}: 1-\left(1-\mathrm{R} 1^{2}\right)\left(1-\mathrm{R} 2^{2}\right)$.

$\mathrm{Q}^{2}: 1-\left(1-0,329^{2}\right)\left(1-0,525^{2}\right)$

$\mathrm{Q}^{2}: 1-(0,892)(0,724)$

$\mathrm{Q}^{2}: 1-0,646$.

$\mathrm{Q}^{2}: 0,354$.

Based on existing data and calculations, the Q-square value is 0.354 so that for this structure model it shows that Q-square value> 0 , it can be concluded that the model has good predictive relevance.

Table 6. Structural Model of Hypothesis

\begin{tabular}{|l|r|r|r|r|r|r|}
\hline & $\begin{array}{c}\text { Sampel } \\
\text { Asli (O) }\end{array}$ & $\begin{array}{c}\text { Sample } \\
\text { Mean (M) }\end{array}$ & $\begin{array}{c}\text { Standar } \\
\text { Deviasi }\end{array}$ & $\begin{array}{c}\mathrm{T} \\
\text { Statistik }\end{array}$ & $\begin{array}{c}\mathrm{P} \\
\text { Values }\end{array}$ & Significancy \\
\hline Job Satisfaction (X1) -> OCB (Z) & $-0,002$ & 0,012 & 0,086 & 0,020 & 0,492 & $\begin{array}{c}\text { Not } \\
\text { significant }\end{array}$ \\
\hline $\begin{array}{l}\text { Job Satisfaction (X1) -> } \\
\text { Organizational Performance (Y) }\end{array}$ & 0,128 & 0,134 & 0,079 & 1,619 & 0,053 & $\begin{array}{c}\text { Not } \\
\text { significant }\end{array}$ \\
\hline Motivation (X2) -> OCB (Z) & 0,261 & 0,269 & 0,077 & 3,411 & 0,000 & Signifikan \\
\hline $\begin{array}{l}\text { Motivation (X2) -> Organizational } \\
\text { Performance (Y) }\end{array}$ & $-0,042$ & $-0,039$ & 0,070 & 0,601 & 0,274 & $\begin{array}{c}\text { Not } \\
\text { significant }\end{array}$ \\
\hline $\begin{array}{l}\text { OCB (Z) -> Organizational } \\
\text { Performance (Y) }\end{array}$ & 0,493 & 0,487 & 0,074 & 6,621 & 0,000 & Signifikan \\
\hline $\begin{array}{l}\text { Organizational Commitment (X3) - } \\
>\text { OCB (Z) }\end{array}$ & 0,449 & 0,435 & 0,069 & 6,515 & 0,000 & Signifikan \\
\hline $\begin{array}{l}\text { Organizational Commitment (X3) - } \\
>\text { Organizational Performance (Y) }\end{array}$ & 0,247 & 0,246 & 0,075 & 3,305 & 0,000 & Signifikan \\
\hline
\end{tabular}

Source: Primary data 2019

Based on the results of the path coefficient in table 5.4 above it can be seen that only the motivation variable (X2) and organizational commitment (X3) have a significant effect on OCB, because it has a T-statistic value > 1.96. then the OCB variable gives a significant effect on Performance $(\mathrm{P})$ with a statistical $\mathrm{T}$ value above 1.96 which is 6.621 . The variable organizational commitment (X3) has a significant influence on organizational performance (Y) with a value of 3,305 higher than 1,96.

In the Path Diagram "OCB Mediation in the Relationship between Job Satisfaction, Organizational Commitment and Motivation to Organizational Performance" with resampling of 173 resppndents with a significant level: 0.05 , with the test type: one tailed presented in the figure below: 
The following is a diagram of the value of the T statistic based on output with SmartPLS Version 3.2.7:

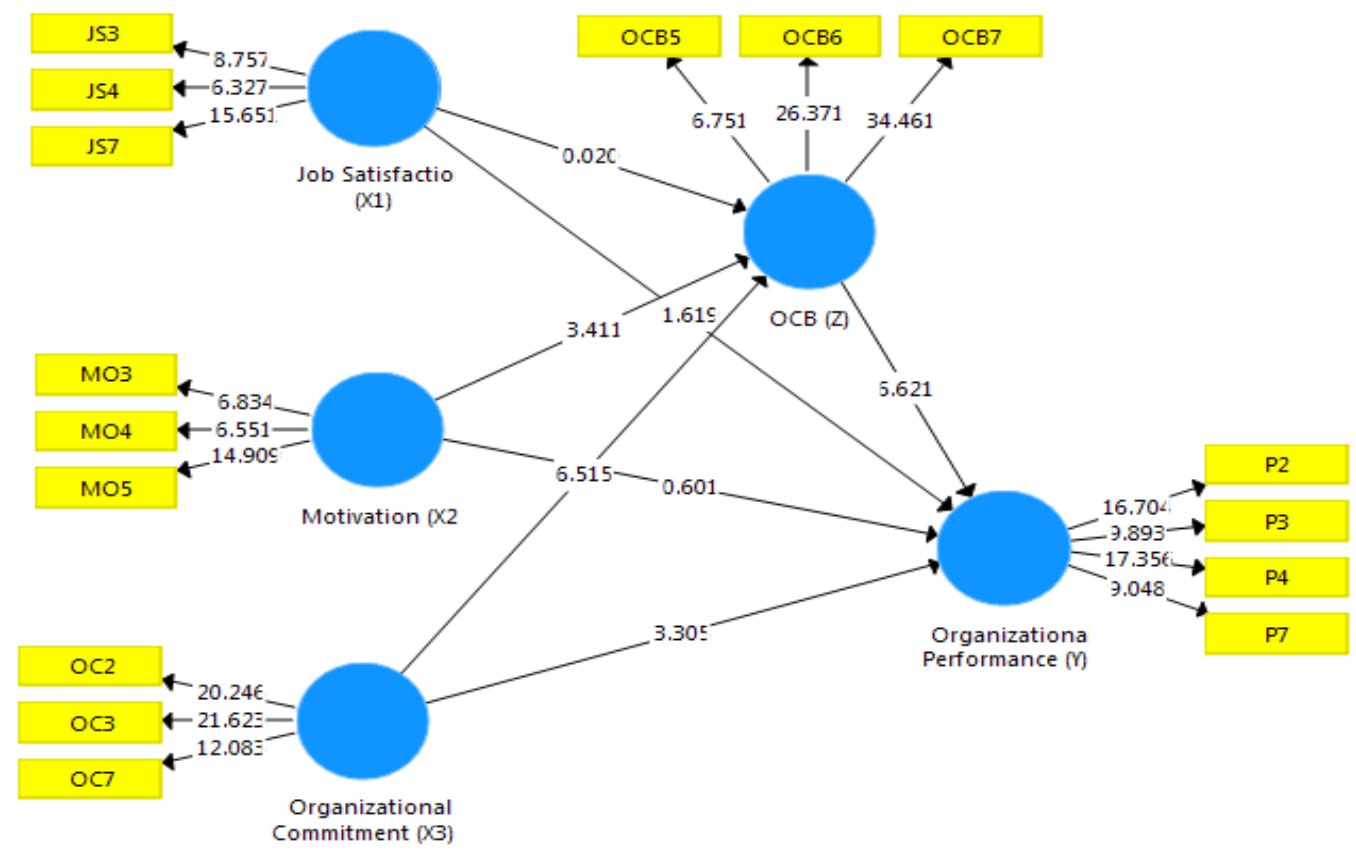

Fig 3. Measurement of Inner Model (Hypothesis)

\subsection{Analyze relationships between it's variables as follows :}

a. Job satisfaction will improve organizational performance with OCB as a mediating variable. The results of previous studies on job satisfaction have a positive effect on OCB; such as research by Hassanreza[11], Sani[14], Sawitri[13], Partono[16], Yumuk[17], Partono[12], Supit[6] and the results of this study indicate that job satisfaction has a positive influence but is not significant to organizational performance by 1,615 . Thus job satisfaction does not affect organizational performance either directly or mediated by OCB. It is possible that there are other variables that can mediate the relationship between job satisfaction and organizational performance. Then the hypothesis Hypothesis 1 is not supported.

b. Motivation will improve organizational performance with OCB as a mediating variable. As a result of previous research, organizational commitment has a positive influence on OCB; such as studies Hassanreza[11], Sani[14], Sawitri[13], and Partono[16]. The results of this study indicate that motivation motivation influences organizational performance fully mediated by $\mathrm{OCB}$ ), the value of the relationship between motivation on organizational performance which 0.601 increased by 5,621 , thus Hypothesis 2 was supported.

c. Organizational Commitment will improve organizational performance with OCB as a mediating variable. As a result of previous research, organizational commitment has a positive influence on OCB; such as studies Hassanreza[11], Sani[14], 
Sawitri[13], and Partono[16]. The results of this study indicate that organizational commitment has a direct positive effect on organizational performance and considering OCB as a mediating variable can have a positive and significant impact on the relationship between organizational commitment to organizational performance. This can be seen in the value of the relationship between organizational commitment to organizational performance resulting in 3,305 exceeding the minimum requirement of 1.96 and by considering OCB, organizational commitment can improve organizational performance by 5,621, thus the hypothesis is supported or accepted.

d. OCB as a mediating variable, is able to provide a positive and significant influence in the relationship between motivation and organizational commitment to organizational performance. Whereas OCB has no influence in the relationship between job satisfaction and organizational performance. By growing the OCB behavior of the employees, it is hoped that it can help management in managing the organization to achieve its goals. Make develop personal qualities of employees who have compliance, feel part of, and always talk about positive things about the company. Even though it has not a significant impact to boost the company's current performance.

\section{Conclusion And Suggestion}

\subsection{Conclusion}

The results of this study indicate that job satisfaction has no effect on organizational performance either directly or mediated by OCB, but motivation influences organizational performance by being fully mediated by OCB. In other hands, organizational commitment affects organizational performance both directly and through OCB, so its mean OCB partially mediated the relationship between organizational commitment and organizational performance.

\subsection{Suggestions}

We suggest karawang post office should be maintain OCB for increase human capital performance and finally will increase the sales, operational excellent and profit, this study should be research on the others Post Office in different location and situation, such as after the management release a new policies or products.

\section{References}

[1] Dessler Gary, Human Resource Management. UK: Pearson, 2013.

[2] A. Robbins Stephen, P and Judge Timothy, Organizational Behavior, 15th ed. UK: Pearson, 2013.

[3] A. Herman, Performance Management, 3rd ed. USA: Peasor, 2013.

[4] Kreitner Robert and Kinicki Angelo, Organizational Behavior, 9th ed. NY: McGrawHill Education, 2010.

[5] M. S. and Glinow, Organizational Behavior-Emerging Knowledge, 7th ed. NY: McGraw-Hill Education, 2015.

[6] I. Yohannes and I. Supit, "Gaya Kepemimpinan Tranformasional .... ( Supit) 351," 
vol. Vol 4 ,No., no. 3, pp. 351-368, 2016.

[7] X. Zhang, F. O. Walumbwa, S. Aryee, and Z. X. G. Chen, "Ethical leadership, employee citizenship and work withdrawal behaviors: Examining mediating and moderating processes," Leadersh. Q., vol. 24, no. 1, pp. 284-297, 2013.

[8] Jarwanto, "No Title No Title," Anal. Pengaruh Iklim Organ. dan Motiv. Terhadap Kinerja Pegawai Badan Pus. Stat. Provinsi Drh. Yogyakarta, vol. 5, no. 9, pp. 246259, 2014.

[9] S. U. W. Khadija Mustaq, MIrza Ashfaq Ahmed, "A Study on Job Satisfaction, Motivation and Organizational Citizenship Behavior," Int. J. Manag. Sci. Bus. Res., vol. 3, no. 11, pp. 1-12, 2014.

[10] W. siti Nurnaningsih, "Pengaruh Kepuasan Kerja, Motivasi Kerja dan Komitmen Organisasi Terhadap Kinerja Melalui Organizational Citizenship Behavior (OCB) Sebagai Variabel Intervening," EEAJ, vol. 2, no. 6, pp. 365-378, 2017.

[11] H. Zeinabadia, "Job satisfaction and organizational commitment as antecedents of Organizational Citizenship Behavior (OCB) of teachers," Procedia - Soc. Behav. Sci., vol. 5, no. 2, pp. 998-1003, 2010.

[12] B. S. L. Arif Partono Prasetio, Syahrizal Siregar, "The Effects of Job Satisfaction and Organizational Commitment on Organizational Citizenship Behavior," Siasat Bisnis, vol. 19, pp. 99-108, 2015.

[13] K. H. Dyah Sawitri, Endang Suswati, "The Impact of Job Satusfaction, Organization Commitment, Organization Citizenship Behavior (OCB) on Employees Performance," vol. 9, no. October 2016, p. 2016.

[14] A. S. Supriyanto, "Role of Procedural Justice, Organizational Commitment and Job Satisfaction on job Performance: The Mediating Effects of Organizational Citizenship Behavior,” Int. J. Bus. Manag., vol. 8, no. 15, pp. 57-67, 2013.

[15] P. M. Podsakoff, S. B. MacKenzie, J. B. Paine, and D. G. Bachrach, "Organizational citizenship behaviors: A critical review of the theoretical and empirical literature and suggestions for future research,” J. Manage., vol. 26, no. 3, pp. 513-563, 2000.

[16] A. Partono Prasetio, T. Yuniarsih, and E. Ahman, "Job Satisfaction, Organizational Commitment, and Organizational Citizenship Behaviour in State-owned Banking," Univers. J. Manag., vol. 5, no. 1, pp. 32-38, 2017.

[17] G. Y. Günay, "Relationship between Job Satisfaction , Organizational Citizenship Behavior and Employee Performance : Sample of Edirne Financial Office Employees in Turkey," Am. Int. J. Contemp. Res., vol. 8, no. 1, pp. 64-65, 2018. 